\title{
NEW THEBAN TOMBS MAPPING PROJECT (NTTMP) PRELIMINARY REPORT, SEASONS 2014-2015 (a)
}

\author{
Abou Zaid, O., ${ }^{1}$ El-Asfar, A., Ezz, A., El-Tayeb, A., Hassan, H., Fathi, O., Azab, M., \\ Beabesh, M., Abd el-Wahab, M., Hassan, A., El-Amir, H. \& Yousef, W. ${ }^{2}$ \\ ${ }^{I}$ Egyptology dep. Faculty of Archaeology, Aswan Univ., Aswan, Egypt \\ ${ }^{2}$ Ministry of Antiquities, Luxor Upper Egypt, Egypt \\ E-mail:omarabouzaid76@gmail.com
}

\begin{abstract}
Thebes (Luxor) and its necropolis were involved in the world heritage list in 1979. The NTTMP project intends to contribute to the archaeological and topographical exploration of the Theban necropolis and it's layout as a world heritage site. Enhancing the value of newly discovered tombs will attract scholars and foreign missions to work and raise funds to preserve these tombs. Many maps were drawn for the Theban necropolis until the end of the $20^{\text {th }}$ century. After the demolition of the modern village of al-Qurna and its houses in 2005, no up-to-date maps were established for the site including the newly discovered tombs. The last complete mapping project for the whole necropolis was accomplished by $F$. Kampp in 1989. Her results were published in 1996. In addition to previous surveys such as the Metropolitan Museum of Fine Arts mapping project and the survey of Porter \& Moss, $P$. Piccione conducted another survey for the site of Sheikh Abdel-Qurna in 2005. One of the main issues of NTTMP therefore is to provide a general map of the entire necropolis including known and newly discovered tombs with full documentation and a consistent numbering system.
\end{abstract}

Keywords: Theban necropolis, Theban tombs, Survey, Mapping.

\section{Introduction}

In the $1960_{\mathrm{s}}$ the largest project of immigration all over Egypt took place in Nubia during the construction of the Asswan High-Dam. In 2005 another immigration project took place on the West-bank of Luxor when the Egyptian authorities decided to move the villagers who lived in the midst of the necropolis and to demolish their houses in order to protect the heritage site. As a result of the demolition of the modern houses, more than a hundred ancient but unknown tombs were uncovered. They remain without documentation and numbering until today. The mud-brick village of al-Qurna was orig- inally located in and around the mortuary temple of Seti I [1]. In his letters K. Lepsius writes on this: "...the old village of Qurna was grouped around a Coptic church at this spot, and was principally situated in the interior of the great outer courts of the temple, but which was afterwards deserted by the inhabitants and exchanged for the rocktombs in the angle of the mountain situated very near at hand" [2]. The settlement later on spread all over the necropolis. The Theban necropolis extends about three kilometers from north to south and is divided into six parts, commonly named after their modern 
Arabic place names: el-Tarif, Dra Abu el-Naga [north, middle and south], alAssasif [north and south], el-Khokha, Sheikh Abd el-Qurna [north and south Elwa, north and south Ramose and Hoza] and Qurnet Murai. Another part of the Theban Necropolis is Deir el-

\section{Project Description}

The ancient Egyptians believed that the tomb is the point of contact between the world of the living and the world of the dead. The necropolis provided a space where both worlds could co-exist symbiotically [4] as in the case of the Theban Necropolis. The people of Qurna, who lived among the tombs, believed that they are the direct descendants of the pharaohs' tomb builders. In the recent past, the people of Qurna housed their livestock in the tombs [5]. The Ministry of Antiquities contributed with 25 million Egyptian pounds to relocate the inhabitants and demolish their houses. After the demolition of the houses, one of the

\section{Project Significance}

The value and significance of the Theban necropolis is not simply that of an ancient cemetery of high officials [6]. It also reflects the correlation and interconnection with the local community as part of the historical sequence from antiquity to modern times. Certain villagers built their houses on the ruins of

\section{Objectives}

The objectives of NTTMP are devided into nine outcomes; they are: 1) Training of young archaeologists and surveyors related to the NTTMP documentation and mapping system. 2) Completion of the necropolis survey including the work of PM, Eigner, Kampp and Picconie; production of high-definition maps of the necropolis area and the tombs that allow experts in archaeology and epigraphy as well as heritage specialists to work with this tool in the area and to obtain better and
Medina with its own cemetery [3]. Each part is occupied by a modern village of the same name. The families who occupied the necropolis had the same traditions and manners in dealing with tombs.

main problems became the accumulation of debris. So the NTTMP was stopped for a longer time until a special project concerned with the removal of debris was accomplished by the SCA in 2009 and another project concerned with recording the modern architecture of the Sheikh Abd el-Qurna area was acco-mplished in 2013. The latter was conducted by ARCE in co-operation with the SCA. After this NTTMP was ready to accomplish the recording of the new tombs within high definition maps and plans and to date them structures. The final outcome of NTTMP shall be a comprehensive atlas of the Theban Necropolis.

the forecourt of a tomb and used the rock cut tomb as a magazine or a cowshed ${ }^{(b)}$. Many tombs were thus buried behind or below these houses and one could not enter or register them, while some registered tombs also became buried since the $1980_{\text {s }}$ as was the case with $\mathrm{TT} 5^{\text {(c) }}$.

faster results in their survey, excavation, and restorations work. 3) Creation of plans and full documentations of the new tombs. 4) Plotting of a general map for the whole necropolis. 5) Setting a consistent numbering system for the new tombs tying with those of PM and Kampp. 6) Classification and dating of the new tombs. 7) Completion of previous research on the Necropolis within the new atlas. 8) The project should be the last stage of the national relocation project. 9) By adding more 
than a hundred hitherto unknown tombs to the necropolis NTTMP will strongly support Luxor's position as a world

\section{Methodology}

The methodology of NTTMP contains five outcomes; they are: 1) Desktop assessment. 2) Data collection.

\section{Field Work}

The field work of the project in the area under study contains initial

\subsection{Dra Abu el-Naga}

The new tombs of Dra Abu elNaga, pl. (1) are spread over the whole area (north, middle and south Dra Abu elNaga). The Majority of these tombs are heritage site in raising funds and support from UNESCO.

3) Field survey including (* GPS survey, * Total station survey) 4) Geophysical mapping. 5) Software processing.

survey and recording and it is divided into three main sectors as follows:

" $T$ "-shaped, only some belong to the "Saff"-type. They were used in modern times for housing and cattle breading.

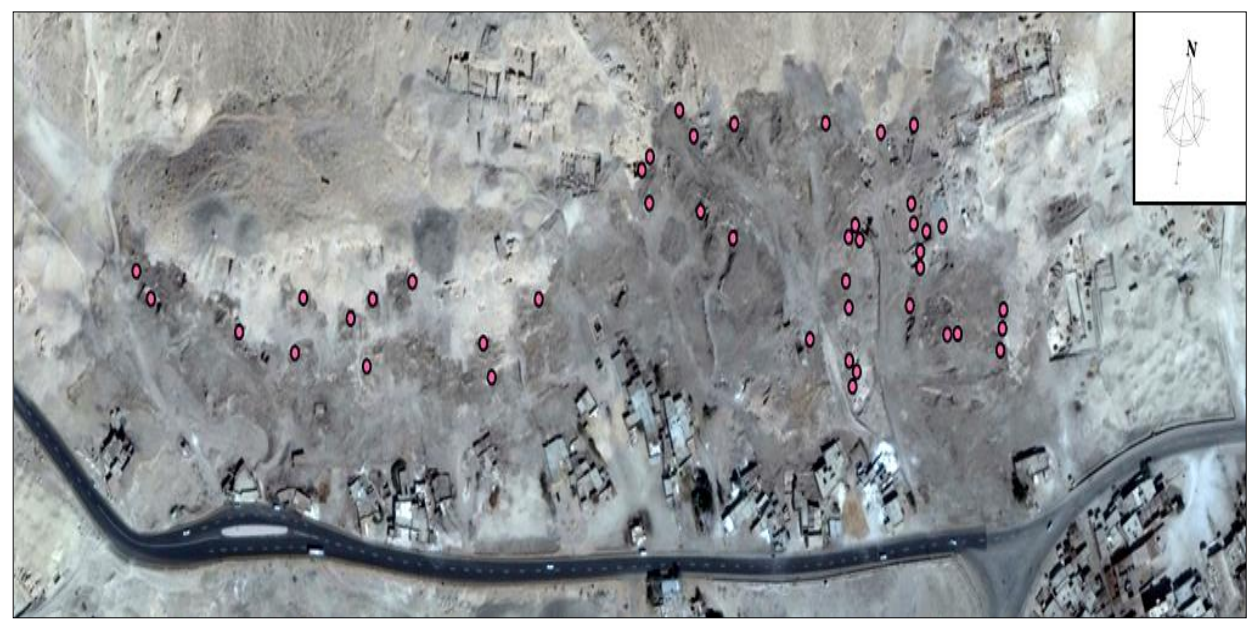

Plate (1) Aerial view of Dra Abu el-Naga with new tombs plotted in

This area contains an important case study 1 , it is a rock-cut tomb designed as "T"'-shape, fig. (1) \& pl. (2-a, $\mathrm{b}, \mathrm{c})$. this tomb consisting of: 1) Forecourt. 2) Entrance. 3) Traverse hall $(10.75 \mathrm{~m} \times 2 \mathrm{~m}$; from the western rock wall an opening leads to another new tomb). 4) Entrance (1m). 5) Elongated hall $(6.80 \mathrm{~m} \times 1.75 \mathrm{~m}) .6)$ Niche. This type emerged in Dyn. XVIII and persisted to the Ramesside period [7] This type of tomb is classified "Vb" according to Kampp's classification [3]. It is a common type, which is represented in i.e. TT $16,17,18,19,26,31,32 \ldots$..etc. $-8-$, 13-, -23-, -43-, -52-....etc.) [7].

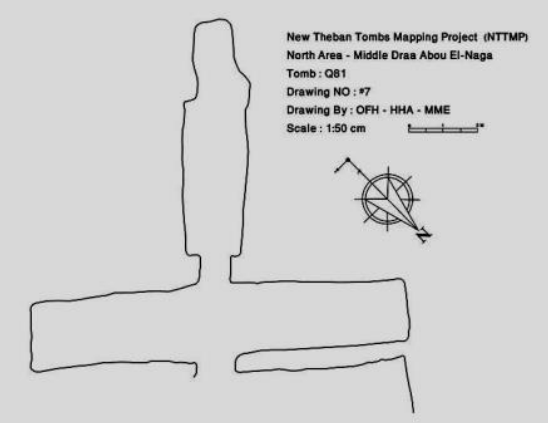

Figure (1) A new rock-cut tomb at Dra Abu el-Naga (case study 1). 

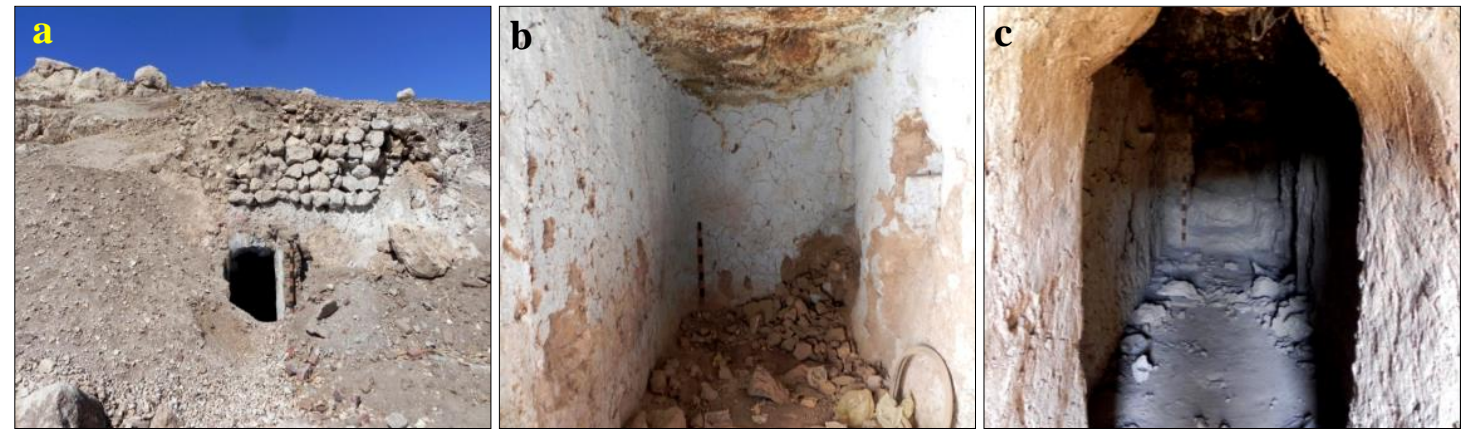

Plate (2) A new rock-cut tomb at Dra Abu el-Naga "Case study-1" showing a. entrance, $\underline{\mathbf{b}}$. traverse

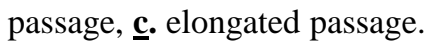

\subsection{Sheikh Abd el-Qurna}

The new tombs at Sheikh Abd elQurna are distinctive by their irregular shape. The majority of these tombs, pl. (3-a, b) were reused in ancient times already. From their reuse in modern times mud-brick walls remain inside the chambers. The entrances are demolished and the remaining colors are now covered by soot.
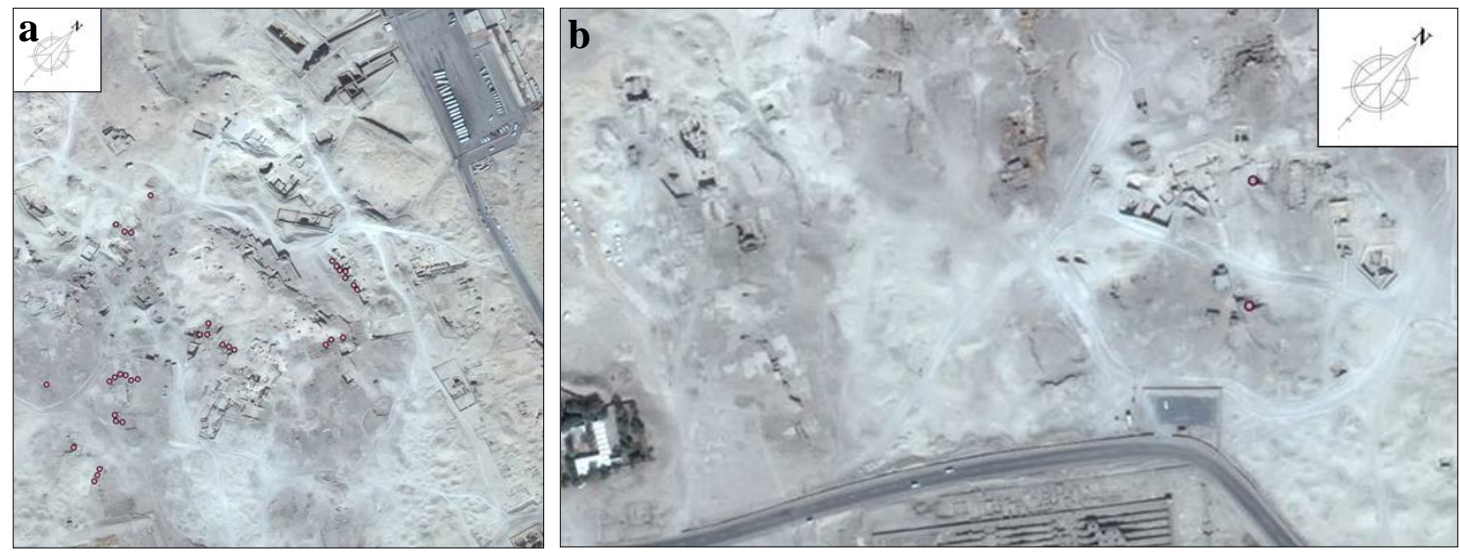

Plate (3) $\underline{\mathbf{a}}$. Aerial view of Sheikh Abd el-Qurna and south Assasif with new tombs plotted in, $\underline{\mathbf{b}}$. aerial view for Sheikh Abd el-Qurna with new tombs plotted in.

The case study 2, which is belonging to this area, , fig. (2) \& pl. (4$\mathrm{a}, \mathrm{b})$ is a rock-cut tomb that is called by the inhabitants of Qurna "rock-cut door". It consits of the following components: 1) Forecourt (unclear). 2) Entrance $(1.30 \mathrm{~m}$, looking north). 3) First squared hall (2.80 $\mathrm{m} \times 2.40 \mathrm{~m}$ with flat roof). 4) Entrance (in the southern corner a rock-cut entrance that was presumably added later, leads to the second squared hall). 5) Second squared hall (irregular shape and presumably added later, $2.50 \mathrm{~m} \times 2.25$ $\mathrm{m})$. The structure presumably belongs to shape I according to Kampp, (tombs without elements) [7] as tombs nos. (TT135, 144, 165, 175, 182,...etc, -1-, -11-, $-25-,-50-,-60-,-98-\ldots$ etc.) [7].

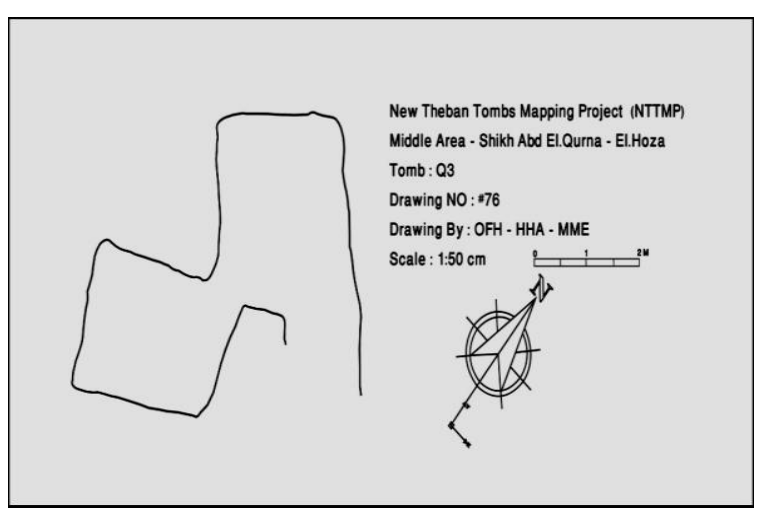

Figure (2) A new rock-cut tomb at Sheikh Abd el-Qurna (case study 2) 

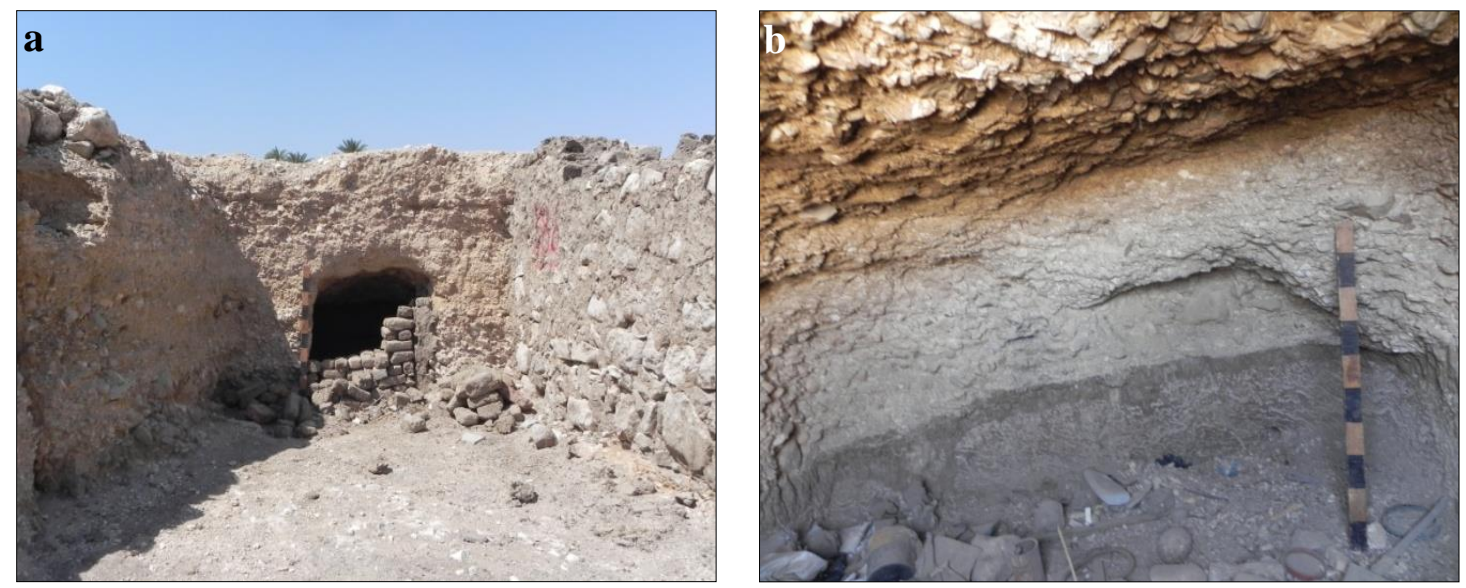

Plate (4) A new rock-cut tomb at Sheikh Abd el-Qurna "case study-2" showing ‥ entrance, $\underline{\mathbf{b}}$. inner room.

\subsection{Qurnet Murai}

Only some of the houses of Qurnet Murai survive, Pl. (5), while the majority has been demolished. During our survey of Qurnet Murai that begun in December 2014, the new tombs of Qurnet Murai were distinguished by: 1) Inscriptions (often covered by soot). 2)

Architectural design. 3) Size. But it seems that the concentration of Qurnet Murai houses is the main cause to keep these new tombs unknown and the survey is in progress to include the new tombs underneath standing houses.

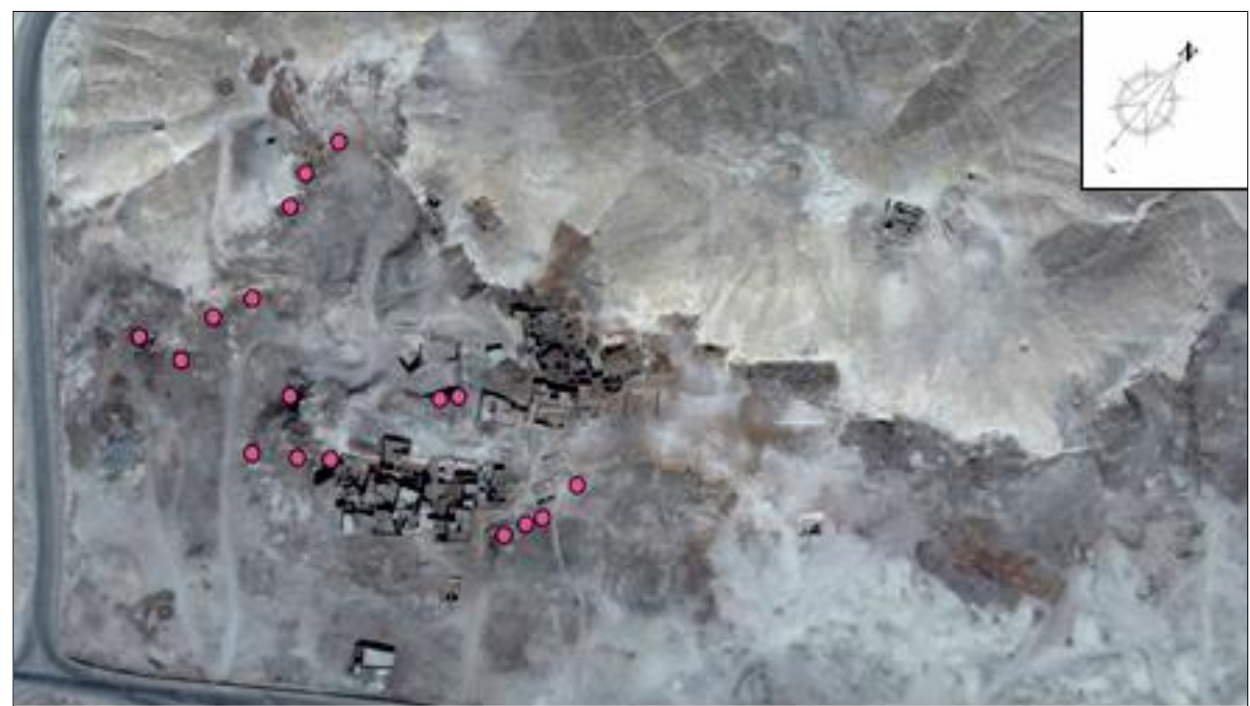

Plate (5) Aerial view of Qurnet Murai with new tombs plotted in

This site contains the case study 3, fig. (3) \& Pl. (6-a, b), it is A Tshaped rock-cut tomb consisting of the following: 1) Forecourt $(15 \mathrm{~m} \times 7.50$ m). 2) Entrance $(1.80 \mathrm{~m})$. 3) Traverse hall $(22 \mathrm{~m} \times 5.50 \mathrm{~m})$ supported by six rock pillars, measuring around $1.25 \mathrm{~m}$ $\mathrm{x} 1.25 \mathrm{~m}$. 4) Entrance $(2 \mathrm{~m})$. 5) Elongated hall $(6.50 \mathrm{~m} \times 2.25 \mathrm{~m}) .6)$ Niche $(3 \mathrm{~m} \times 1.50 \mathrm{~m})$ with a tunnel to its left of supposedly late date; the tunnel's entrance is of irregular shape and measures around $1.50 \mathrm{~m}$. This tomb is distinguished by a thick red plaster with traces of colored inscriptions, which are extensively covered by soot. The shape and design of this tomb is classified as "Kampp" VIIa like tombs (TT 29, 30, 41, 50, 65, 70, 71, etc., -3-, -5-, -37-, $58-,-70-. . . e t c).[7]$. 


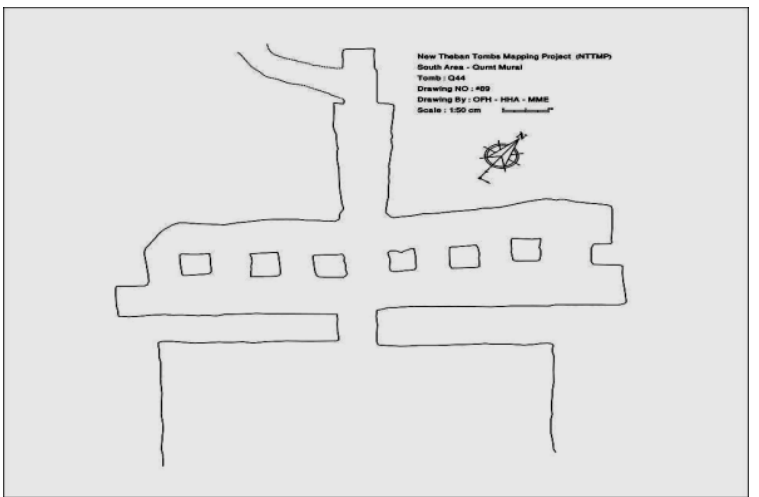

Figure (3) A new rock-cut tomb of Qurnet Murai (case study 3).
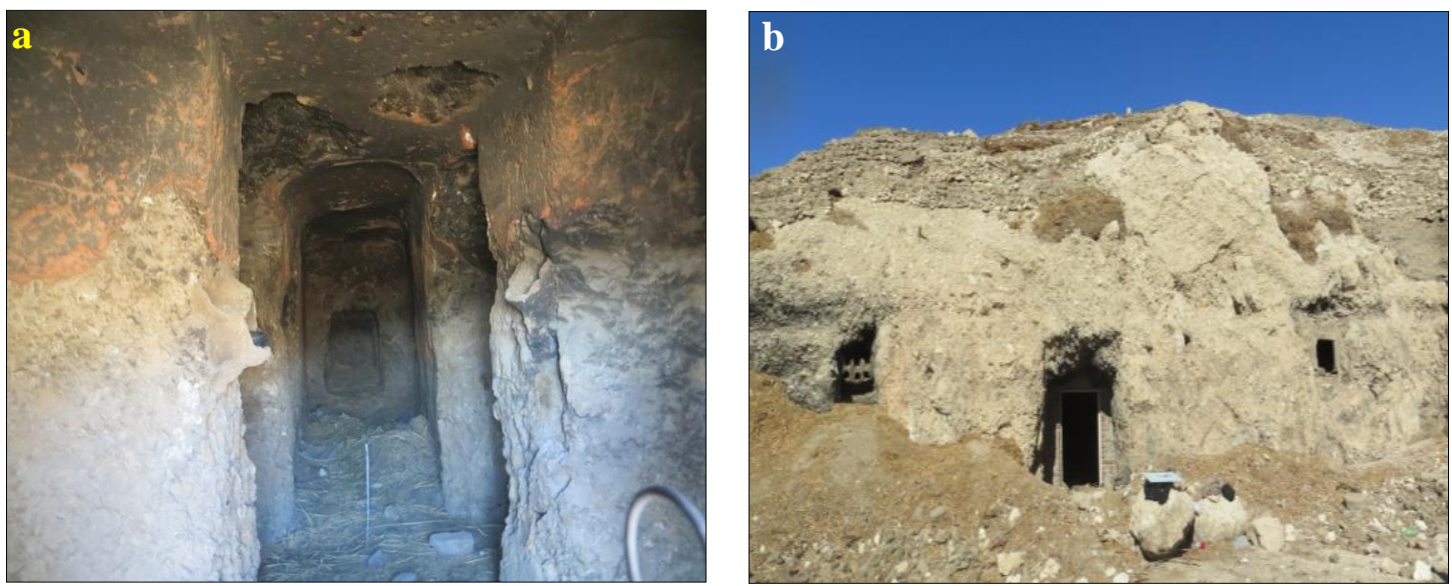

Plate (6) A new rock-cut tomb of Qurnet Murai "Case study-3" showing ‥ entrance, $\underline{\mathbf{b}}$. elongated passage with niche.

\section{Conclusion}

The last general survey of the Theban necropolis was conducted by F. Kampp in 1989 and published in 1996 when the necropolis was still inhabited by the people of Qurna. In 2006 Peter Piccione undertook the last survey on a map showing the tombs as points from North Assasif to South Assasif where only a few houses were demolished. After nearly all houses had been demolished in 2008 and the accumulations of debris had been removed, NTTMP started to survey and record all new tombs of the Theban necropolis. The project aims at the compilation of an atlas for the site, including a general map, plans and photographs of the old and newly numbered tombs within one consistent system.

\section{Endnotes}

(a) I am indebted to the Ministry of Antiquities (Prof. Dr. M. El-Damaty minister of antiquities, Dr. M. Amin, secretary general of the $S C A$, Dr. M. Afifi, Dr. M. Ismail, Mr. H. Abu ElAzm, Mr. A. Karrar, Mr. S. Eid, Dr. M. Waziri, Mr. T. El-Aziz, Dr. M. Abd El-Aziz, Mr. M. Abdellah, Mr. A. Senari, Mr. R. Ali, Mr. F. Yassin, Mr. E. Nubi, Mr. A. Arabi, Mr. M. El-Saghier, Mr. A. Elleisy, Mr. B. Abdel-Gaber, H. Arabi \& my gratitude to J. Shairman and ARCE in Egypt (Luxor)

(b) Like e.g.TT291 Irytiaru, one of the largest tombs of South Assasif from the $25^{\text {th }}$ Dyn. It was occupied by the Abd El-Rasul family and remains still unpublished. A large conservation and restoration project 
is in progress, conducted by an Egyptian-American mission.

(c) We rediscovered this tomb in 2008 during our work in Dra $\mathrm{Abu}$ elNaga. We found an iron door with

\section{References}

[1] Simpson, C., (2003). Modern Qurna-pieces of an historical jigsaw, in: Strudwick, N. \& Taylor, J. (ed.), The Theban Necropolis: Past, Present and Future, British Museum Press, London, pp. 244-249.

[2] Lepsius, R.,(1853) Letters from Egypt, Ethiopia and the Peninsula of Sinai. Henry G. Bohn, York Street, Covent Garden, London.

[3] Kampp, K., (2003) The Theban necropolis: An overview of topography and tomb development from the middle kingdom to the Ramesside period, in: Strudwick, N. \& Taylor, J. (ed.), The Theban Necropolis: Past, Present and Future, British Museum Press, London, pp. 2-10. wooden label (TT15). A German mission applied to work in this tomb in 2003, but its location remains unknown.

[4] Dodson, A., Ikram, S., (2008) The tomb in ancient Egypt: Royal and private sepulchers from the early dynastic period to the Romans, Thanes \& Hudson, London.

[5] McDermott, B., (2006) Death in ancient Egypt, Sutton Publishing Limited, UK.

[6] Allen, J., (2003) The high officials of the early middle Kingdom, in: Strudwick, N. \& Taylor, J. (ed.), The Theban Necropolis: Past, Present and Future, British Museum Press, London, pp. 14-27.

[7] Kampp, F., (1996) Die Thebanische Nekropole, Vol. I, Verlag Philipp Von Zabern, Mainz. 